logos_i_ethos_2020_1_(53), s. 77-95

DOI: http://dx.doi.org/10.15633/lie.3690

Tadeusz Biesaga SDB

https://orcid.org/0000-0003-0863-4422

Uniwersytet Papieski Jana Pawła II w Krakowie

\title{
Autoteleologia osoby a teleologia natury w antropologii Karola Wojtyły
}

\section{Przeciwstawienie czy synteza autoteleologii osoby $\mathrm{z}$ teleologią natury?}

Jeżeli arystotelesowsko-tomistyczna filozofia bytu w ujęciu człowieka i w ujęciu tego, co dobre dla niego, posługuje się głównie teleologią natury ludzkiej, to nowożytna i współczesna filozofia podmiotu, filozofia świadomości czy „ja” transcendentalnego posługuje się w tym

Tadeusz Biesaga SDB - ks. prof. dr hab., filozof, etyk, bioetyk, teoretyk etyki medycznej, kierownik Katedry Bioetyki na Wydziale Filozoficznym UPJPII w Krakowie. Rozwija personalistyczną etykę, bioetykę i etykę medyczną. Z punktu widzenia personalizmu realistycznego przeprowadza krytykę utylitaryzmu i kontraktualizmu w etyce ogólnej, bioetyce i etyce medycznej. względzie autoteleologią świadomego i wolnego podmiotu osobowego. Ujęcia te mogą się radykalnie sobie przeciwstawiać, ale mogą też zbliżać się do siebie. Powstaje pytanie, czy Karol Wojtyła w swej propozycji poszedł za którymś z tych nurtów filozoficznych, czy też dokonał w Osobie i czynie swoistej syntezy obu ujęć, zarówno w koncepcji człowieka, jak i u podstaw etyki.

Jeśli Osobe i czyn opublikowaną w $1969^{1}$ roku potraktować jako zaprezentowanie przez Karola Wojtyłę swojej własnej antropologii, to okres poprzedzający można uznać za krytyczne poszukiwanie 
przeprowadzonej w tym dziele syntezy antropologicznej, a okres następujący po niej - za jej rozwinięcie i kontynuację. W obu wymienionych okresach Autor Osoby i czynu najwięcej korzystał z filozofii arystotelesowsko-tomistycznej i fenomenologii. Nietrudno dostrzec, że przed opublikowaniem swej dojrzałej koncepcji człowieka Wojtyła wyraźnie nawiązywał do filozofii tomistycznej. Świadczą o tym choćby wykłady dla studentów z 1949 roku zatytułowane Rozważania o istocie człowieka ${ }^{2}$, krytyka etyki Maksa Schelera w habilitacji obronionej w 1953 roku, zatytułowanej Ocena możliwości zbudowania etyki chrześcijańskiej przy założeniach systemu Maksa Schelera, jak też wygłoszone w latach 1954-1956 Wykłady lubelskie oraz opublikowane w latach 1957-1958 teksty z etyki tomistycznej zebrane jako Elementarz etyczny.

Krytyczne stanowisko względem antropologii i etyki tomistycznej znajdujemy m.in. w szkicu podstaw etyki napisanym w roku 1972 zaraz po ukazaniu się Osoby $i$ czynu, zatytułowanym Człowiek w polu odpowiedzialności $i^{3}$ oraz w referacie wygłoszonym w 1972 roku we Włoszech i w Stanach Zjednoczonych, zatytułowanym Transcendencja osoby w czynie a autoteleologia człowieka ${ }^{4}$.

Patrząc całościowo na owe wymienione trzy nurty myślenia, które umownie dla potrzeb niniejszej analizy możemy nazwać nurtem tomistycznym, fenomenologicznym i oryginalnym - własnym, można zauważyć, że wysiłki tego filozofa zmierzały do syntezy fenomenologii i tomizmu, szerzej do syntezy filozofii świadomości, czy filozofii podmiotowej z filozofią bytu, z filozofią przedmiotową.

Już we wstępie do Osoby i czynu Wojtyła za główne zadanie tego dzieła uznał dokonanie syntezy filozofii świadomości i filozofii bytu. Chodziło mu o scalenie ujęcia człowieka na podstawie posiadanego doświadczenia wewnętrznego i doświadczenia zewnętrznego, mimo że doświadczenia te nie są współmierne i niejako dostarczają nam innej wiedzy. Wojtyła

2 K. Wojtyła, Rozważania o istocie człowieka, Kraków 1999.

3 K. Wojtyła, Człowiek w polu odpowiedzialności, red. A. Szostek, Rzym-Lublin 1991.

4 K. Wojtyła, Transcendencja osoby w czynie a autoteleologia człowieka, w: K. Wojtyła, „Osoba i czyn" oraz inne studia antropologiczne, red. T. Styczeń, W. Chudy, J. W. Gałkowski, A. Rodziński, A. Szostek, Lublin1994, s. 477-490 (Człowiek i Moralność, 4). 
chciał przezwyciężyć - jak sam zaznacza - rozszczepienie współczesnej filozofii na filozofię bytu i filozofię świadomości. Doceniał poszerzenie naszej wiedzy przez filozofię świadomości, ale nie zgadzał się w niej z negacją filozofii bytu ${ }^{5}$. „Pozostając na gruncie filozofii bytu - pisał we wprowadzeniu do Osoby i czynu - chcielibyśmy skorzystać z tego wzbogacenia. Próba prawidłowego scalenia w koncepcji osoby i czynu tych zrozumień, jakie wyłaniają się z doświadczenia człowieka w obu jego aspektach, musi w jakiejś mierze stać się próbą scalenia dwóch orientacji filozoficznych, poniekąd dwu filozofii”".

Powyższe dążenie do syntezy zauważyli już pierwsi wybitni dyskutanci z Osobq i czynem, zarówno fenomenologowie, jak i tomiści, których stanowiska zostały opublikowane w tomie 5-6 "Analecta Cracoviensia” 1973-1974.

„Nie będzie zapewne błędem, gdy powiem, zaznaczył w tej dyskusji Józef Tischner, że książka Osoba i czyn narodziła się z potrzeby syntezy. Chodziło o syntezę myślenia o osobie właściwego dla nurtu arystotelesowsko-tomistycznego z nurtem fenomenologicznym, przy czym w nurcie tym szczególnie preferowaną okazuje się metoda eidetyczno-opisowa, którą posługiwał się M. Scheler, a u nas R. Ingarden. [...] Aby synteza tego rodzaju mogła się powieść, trzeba było podjąć zadanie podwójnej interpretacji: interpretacji wybranych tez filozofii tradycyjnej (tez o osobie, o akcie, o możności) oraz tez pochodzących z fenomenologii. Celem interpretacji jest ukazanie, w jaki sposób tezy te się postulują, podtrzymują, uzupełniają"7 . To dzięki umiejętnej syntezie „książka otwarła i nadal będzie otwierać drzwi do współczesności tym, stwierdza Tischner, którzy swe przywiązanie do filozofii związali z równym przywiązaniem do tradycji”.

Również tomiści, dyskutując nad Osoba i czynem, analizowali, na ile zaproponowana przez Wojtyłę synteza się powiodła. Radykalnie

5 Zob. K. Wojtyła, Osoba i czyn, dz. cyt., s. 22.

$6 \quad$ K. Wojtyła, Osoba i czyn, dz. cyt., s. 23

7 J. Tischner, Metodologiczna strona dzieła „Osoba i czyn”, „Analecta Cracoviensia” 5-6(19731974), s. 85.

${ }^{8}$ J. Tischner, Metodologiczna strona dzieła „Osoba i czyn”, dz. cyt., s. 87. 
w tej kwestii wypowiedział się Jerzy Kalinowski. Jego zdaniem w Osobie i czynie Wojtyła zastąpił Tomaszowe, „metafizyczne pojęcie natury przez pojęcie naukowe, przejęte przez fenomenologię"9. „Według Akwinaty - wyjaśniał on - [...] naturą jest istota danego bytu jako podłoże właściwych mu działań. Przy takim rozumieniu terminu «natura» od razu widać, iż człowiek - jeśli pojmuje się jego istotę zgodnie ze św. Tomaszem z Akwinu - z natury swej jest osobą transcendującą się i integrującą - by zachować wyrażenia specyficzne ks. Kardynała - w swym czynie. Dlaczego zatem, mając na celu właśnie scalenie metafizyki i fenomenologii, nadawać terminowi «natura» znaczenie całkiem odmienne, przy którym wyraz ten oznacza jedynie tę część natury ludzkiej w metafizycznym znaczeniu, na którą wskazuje pierwszy składnik filozoficznej definicji człowieka «zwierzę» i która skutkiem tego jest podłożem uczynnień, by znów posłużyć się językiem Autora? [...] Takie zacieśnione pojęcie natury - stwierdza Jerzy Kalinowski zmusza Autora [Osoby i czynu - dod. T. B.] do stałego przeciwstawiania natury osobie" 10 .

W tej samej kwestii Mieczysław A. Krąpiec sformułował nieco odmienną opinię. „Cała tradycja literatury filozoficznej i teologicznej stwierdził - przedstawiała nam koncepcję osoby od strony zdeterminowanych potencjalności i zdeterminowanych źródeł działania człowieka. Mówiąc skrótowo, to poprzez analizę physis - natury starano się dojść nie tylko do ustalenia struktury bytu ludzkiego, ale także do odkrycia momentu osobowego człowieka [...]"11. Zauważył on, że Wojtyła w swym dziele skupił się wprost na owym szczytowym momencie, jakim jest osoba, natomiast mniej zajmował się problemem natury. W kwestii relacji między osobą a naturą Krąpiec zaznaczył: „Jeślibyśmy zatem pojęli osobę jako źródło działania samo się determinujące,

\footnotetext{
9 J. Kalinowski, Metafizyka i fenomenologia osoby ludzkiej. Pytania wywołane przez „Osobe i czyn”, „Analecta Cracoviensia” 5-6 (1973-1974), s. 70.

10 J. Kalinowski, Metafizyka i fenomenologia osoby ludzkiej, dz. cyt., s. 70.

11 A. M. Krąpiec, Książka Kardynała Wojtyly monografią osoby jako podmiotu moralności, „Analecta Cracoviensia” 5-6 (1973-1974), s. 58.
} 
a nie «zdeterminowane», to opozycja między naturą a osobą stałaby się ostrzejsza"12. Pytał, czy w dziele Wojtyły właśnie taka ostra opozycja występuje. Jego zdaniem „w zarysowanej koncepcji antropologii filozoficznej rozumienie człowieka oscyluje pomiędzy wyakcentowaniem roli osoby jako samo-istniejącego «ja» (czyli bytu-podmiotu w akcie podmiotowania) natury rozumnej. Natura i jej rola, jej struktura i sposoby działania domagają się również uwzględnienia i przeanalizowana. [...] Dzieło Wojtyły - jego zdaniem - za mało wyakcentowuje rolę «natury» człowieka. A przecież rozumienie człowieka przebiega na liniach spięcia się właśnie natury, czyli zdeterminowanych (od zewnątrz także!) źródeł działania i osoby, jako bytu wolnego samodeterminującego się do wyłonienia czynu"13.

Jerzy Gałkowski zauważył, że Wojtyła w Osobie i czynie posługuje się różnymi pojęciami natury: „raz pojęciem natury - przyrody”, innym razem pojęciem natury „równoznacznym ze stałością bytu, z jego substancjalnością" lub „pojęciem natury - struktury istotnej lub właściwej danemu bytowi" ${ }^{14}$. Ze względu na trudności zrozumienia, które z używanych pojęć jest zasadnicze oraz jaka jest ich relacja do innych pojęć, takich jak: „ja”, „osoba”, „człowiek”, „natura osoby”, „,nie można się zorientować - zdaniem Gałkowskiego - w jakim znaczeniu i zakresie doszło do syntezy"15.

Znany tomista Mieczysław Gogacz pozytywnie zinterpretował Wojtyłowskie rozróżnienie „człowiek działa”, „coś dzieje się w człowieku”, przyporządkowując te terminy pojęciu „,człowiek”. „Osoba - stwierdza on - jest wobec tego człowiekiem ze względu na to, że jest świadomym siebie sprawcą swych działań. Natura jest człowiekiem, w którym ukazujemy podmiot dynamizmu, to, co w nim się dzieje. Osoba i natura

12 A. M. Krąpiec, Książka Kardynała Wojtyły monografia osoby jako podmiotu moralności, dz. cyt., s. 58 .

13 A. M. Krąpiec, Książka Kardynała Wojtyły monografia osoby jako podmiotu moralności, dz. cyt., s. 61

14 J. Gałkowski, Natura, osoba, wolność, „Analecta Cracoviensia” 5-6 (1973-1974), s. 181.

15 J. Gałkowski, Natura, osoba, wolność, dz. cyt., s. 181. 
są więc w człowieku dwoma podmiotami dwu różnych działań: działań świadomych i tego, co nieświadomie zachodzi w człowieku" ${ }^{\prime 16}$.

Podobnie Tadeusz Wojciechowski podkreślał, że Wojtyła w nowy sposób ukazał jedność duchowo-cielesną człowieka, która to jedność psychofizyczna była dotychczas przedstawiana przez tomistów zbyt abstrakcyjnym językiem. Jego zdaniem „wkład Autora (Osoby i czynu - dod. T. B.) do zagadnienia duszy ludzkiej i jej stosunku do ciała polega na zastosowaniu metody fenomenologicznej i wykazaniu, o ile wzbogaca ona problematykę duszy i o ile podprowadza nas do głębszego zrozumienia pierwiastka duchowego i cielesnego w człowieku"17.

Dokładną argumentację za tym, że w Osobie i czynie mamy do czynienia $z$ oryginalną i udaną syntezą filozofii świadomości z filozofią bytu, teleologii natury ludzkiej z autoteleologią osoby przedstawił ks. (obecnie kard.) Marian Jaworski. Jego zdaniem Wojtyła w swym dziele przezwyciężył subiektywizm czy idealizm w koncepcji człowieka, ukazał związek pomiędzy podmiotowym przeżyciem podmiotu a ontologicznym suppositum $^{18}$. „Suppositum - czytamy w Osobie i czynie - wskazuje na samo bycie podmiotem albo też wskazuje na podmiot jako byt. Ów podmiot jako byt tkwi u podstaw każdej struktury dynamicznej, każdego działania oraz dziania się, każdej sprawczości oraz podmiotowości. Jest to byt realny, byt - «człowiek» realnie istniejący, a w konsekwencji też realnie działający" ${ }^{19}$.

Podsumowując powyższą, ważną dyskusję nad Osobą i czynem, można stwierdzić, że zarówno polscy fenomenologowie, jak i tomiści byli zaskoczeni nowością zastosowanej metody oraz nowością odmiennego od nich ujęcia człowieka. Nie bardzo wiedzieli, jak się wobec tego

16 M. Gogacz, Hermeneutyka „Osoby i czynu” (Recenzja książki Księdza Kardynała Karola Wojtyły Osoba i czyn, Kraków 1969), Analecta Cracoviensia” 5-6 (1973-1974), s. 136.

17 T. Wojciechowski, Jedność duchowo-cielesna człowieka w książce „Osoba i czyn”, „Analecta Cracoviensia" 5-6 (1973-1974), s. 197.

18 Zob. M. Jaworski, Koncepcja antropologii filozoficznej w ujęciu Kardynała Karola Wojtyly (Próba odczytania w oparciu o studium „Osoba i czyn”), „Analecta Cracoviensia” 5-6 (1973-1974), s. 102.

19 K. Wojtyła, Osoba i czyn, dz. cyt., s. 75. 
nowatorskiego dzieła zachować. Niektóre wypowiedzi szły w kierunku nazwania owej syntezy antropologicznej fenomenologią tomizującą (Antoni B. Stępień), inne formułowane były z pozycji własnych systemów filozoficznych (J. Kalinowski, J. Tischner). Jeszcze inne opinie opowiadały się za udaną syntezą (M. Jaworski, M. Gogacz), w której przezwyciężono dualizm antropologiczny i stworzono oryginalną i realistyczną koncepcję człowieka.

Radykalnie krytyczne uwagi co do syntezy dwóch nurtów filozoficznych w antropologii Wojtyły wynikały $\mathrm{z}$ narzucania tej syntezie przez dyskutantów założeń własnych systemów filozoficznych. Kalinowski z góry wykluczył możliwość syntezy filozofii świadomości z filozofią bytu, a to dlatego, że tę pierwszą pojął jako filozofię „ja” transcendentalnego. Stąd jego podejrzenie, że Wojtyła inspiruje się pokantowską filozofią oderwanego od natury podmiotu. Tischner również odwołał się do swojego sposobu filozofowania i sugerował, że Wojtyła, chcąc uniknąć niebezpieczeństwa reifikacji podmiotu osobowego, powinien iść w tym samym kierunku, w którym poszedł Scheler, gdy odsłaniał osobę w jej intencjonalnych, aksjologicznych aktach emocjonalnych, lub Heidegger, gdy ujawniał, że osoba nie tyle jest, jak głosi tomizm, lecz staje się osobą ${ }^{20}$.

Trudno się dziwić, że zarówno tomiści, jak i fenomenologowie, trzymając się swoich mistrzów i systemów myślenia, byli niezadowoleni z zaproponowanej przez Wojtyłę trzeciej drogi, którą albo wykluczali, albo której nie brali pod uwagę. Jeśli jednak założymy, że trzecia droga, czyli synteza dwóch nurtów myślenia, pozwoliłaby przełamać dualizm antropologiczny pokantowskiej filozofii transcendentalnej, to droga taka jest czymś bezcennym.

Dotychczas napisano już wiele artykułów w kwestii syntezy w Osobie i czynie filozofii świadomości i filozofii bytu. Obok tego metodologicznego problemu niemniej ważna jest kwestia syntezy autoteleologii osoby $\mathrm{z}$ teleologią natury ludzkiej. Jest ona w tym ważna, że synteza taka 
mogłaby w jakiejś mierze przezwyciężyć pokartezjański i pokantowski dualizm w koncepcji człowieka.

\section{Teleologia natury ludzkiej}

Z Wojtyłowską analizą natury ludzkiej spotykamy się w publikacjach przed Osoba i czynem, czyli w Wykładach lubelskich z lat 1954-1956 ${ }^{21}$ oraz w Elementarzu etycznym $\mathrm{z}$ lat 1957-1958. Mamy w nich do czynienia z dokładnym studium dzieł św. Tomasza czy nawet Arystotelesa oraz przystępnym opisem natury człowieka i prawa naturalnego. Mimo że są to teksty przystępne dla szerszego grona, to jednak są one pisane już po habilitacji, po krytycznej ocenie etyki fenomenologicznej Schelera, a więc są publikowane przez samodzielnie myślącego filozofa, wkraczającego na własną drogę analiz filozoficznych. Ponieważ w habilitacji Wojtyła przyjął krytyczną postawę wobec etyki fenomenologicznej, która nie potrafiła objąć całej rzeczywistości faktu etycznego, a w nim szczególnie sprawczości jako nieodzownej właściwości osoby ludzkiej, to $\mathrm{w}$ wymienionych wyżej tekstach dokładnie przestudiował prezentowane przez św. Tomasza podstawy metafizyczne i antropologiczne etyki. W tekstach tych mamy zwięzły wykład realistycznych podstaw etyki wraz z odrzuceniem idealizmu, naturalizmu czy fenomenalizmu w ujęciu natury ludzkiej. Wojtyła posługuje się w nich tomistyczną metodą filozofii bytu. „Wedle realistycznych założeń systemu św. Tomasza - pisze - rozum przede wszystkim poznaje byt, a cechy i właściwości poznaje w nim jako cechy i właściwości określonego bytu. [...] W przeciwieństwie do przypadłości - pisze dalej - sam byt substancjalny jest podmiotem istnienia i działania: bytuje i działa samoistnie. I właśnie w działaniu uwydatnia się jego natura, dochodzą w nim bowiem do głosu wszystkie możliwości, które byt kryje w sobie [...]. I otóż takie urzeczywistnienie tego wszystkiego, czym dany byt jest w możności stanowi z natury jego cel, odpowiada bowiem naturze i dlatego przyczynia się do zbudzenia

${ }^{21}$ K. Wojtyła, Wykłady lubelskie, red. T. Styczeń, J. W. Gałkowski, A. Rodziński, A. Szostek, Lublin 1986 (Człowiek i Moralność, 3). 
dążności, aktywności danego bytu. [...] Dobrem jest to, co wywołuje dążenie, co pobudza do działania" 22 .

Opis natury ludzkiej i jej teleologii rozwijany jest więc z pozycji ujęcia człowieka jako bytu wśród innych bytów, z pozycji dynamizmów substancji, takich jak akt i możność, naturalne tendencje bytu do realizacji swoich potencjalności. Rozum, aby mógł trafnie określić, co jest dobre, a co jest złe, winien rozeznać, co jest zgodne $\mathrm{z}$ naturą ludzką, $\mathrm{z}$ jej celowością, a co jest $\mathrm{z}$ nią sprzeczne. Potrafi on rozróżnić bonum delectabile, utile i bonum honestum, czyli pewne uporządkowane hierarchicznie dobra, z których to ostatnie udoskonala nasze człowieczeństwo jako takie. $\mathrm{W}$ tym bowiem przypadku mamy do czynienia $\mathrm{z}$ doskonałością moralną. „Doskonałość moralna - stwierdza Wojtyła - jest w ten sposób głównym i centralnym aktem natury ludzkiej, wobec czego wszystkie inne udoskonalenia człowieka do niej się w jakiś sposób sprowadzają i przez nią dopiero stają się doskonałościami ludzkimi we właściwym słowa tego znaczeniu"23.

Tak więc „natura ludzka - stwierdza Wojtyła - jest źródłem norm, rozum bowiem jako jej władza, jako energia z nią ściśle związana, określa zasady postępowania wedle tego, jak rozeznaje drogi doskonalenia się bytu ludzkiego w ramach porządku bytów" 24 .

$\mathrm{Z}$ tego rozeznania rodzi się powinność moralna, rodzą się normy moralne. Rozum ludzki nie jest sam z siebie prawodawcą, ale tym, który rozpoznaje prawo naturalne, a nawet odkrywa, że jest ono zakorzenione w prawie odwiecznym w Bogu. To Bóg jest Dawcą tego prawa, a rozum ludzki jedynie tym, który je odczytuje. Skłonności naturalne do zachowania swego życia, do życia w rodzinie i w społeczności, do szukania prawdy, w tym prawdy ostatecznej o Bogu, wskazują na podstawowe dobra, które rozum jako dobra osoby ludzkiej rozpoznaje i na poziomie sumienia zobowiązuje nas do ich realizacji. Gdybyśmy przypisali

22 K. Wojtyła, Elementarz etyczny, w: K. Wojtyła, Aby Chrystus się nami posługiwał, Kraków 1980, s. 140.

${ }^{23}$ K. Wojtyła, Elementarz etyczny, dz. cyt., s. 141.

24 K. Wojtyła, Elementarz etyczny, dz. cyt., s. 142-143. 
rozumowi ludzkiemu rolę prawodawcy, jak to jest np. w pozytywizmie prawnym, to wtedy takie nakazy obowiązywałyby w sumieniu innych ludzi, co prowadziłoby do łamania sumień. Prawo stanowione nie jest źródłem norm moralnych, staje się prawem o tyle, o ile jest zgodne z prawem naturalnym. Ważna rola rozumu do promulgacji prawa nie zwalnia go od właściwego jego odczytania w naturze ludzkiej.

W sumie, z pozycji tomistycznej filozofii bytu, Wojtyła akceptuje realistyczne ujęcie człowieka, czyli jego naturę, inklinacje naturalne, teleologię natury ludzkiej i podstawowe dobra, do których człowiek dąży, natomiast otwiera sobie już pole do dalszych badań, pytając, czy etyka ta ma być teorią szczęścia, etyką eudajmonistyczną, czy da się w niej zagwarantować, istotną dla moralności, bezinteresowność?

Początkowy zarys odpowiedzi na te pytania jest dość ostrożny i wyważony. „Etyka - czytamy - nie jest z istoty swojej nauką o szczęściu, jest bowiem nauką normatywną - a szczęście samo stoi poza normą i ponad nią. Jest ono celem natury, nie zaś przedmiotem wyboru, podczas gdy norma odnosi się tylko do tego, co jest przedmiotem wyboru. Przedmiotem wyboru zawsze jest jakaś droga, którą człowiek powinien iść. Szczęście zaś nie jest drogą, ale celem każdej drogi człowieka"25. W rozwiązaniu tego problemu Wojtyła przestawia kolejność motywów w działaniu, stwierdzając, że „człowiek dojrzewa do szczęścia przez doskonałość moralną"26. Widoczny jest w tym początek reinterpretacji etyki eudajmonistycznej w kierunku etyki perfekcjonistycznej, a w przyszłości personalistycznej, w której element godności, wolności i bezinteresowności będzie jeszcze mocniej uwypuklony.

\section{Autoteleologia osoby}

W referacie Transcendencja osoby w czynie a autoteleologia człowieka wygłoszonym na uczelniach zagranicznych w 1976 roku Wojtyła, na podstawie tego, co osiągnął w Osobie i czynie, wyciąga wnioski w kwestii au- 
toteleologii osoby. Przywołuje najpierw rozumienie człowieka w ramach arystotelesowsko-tomistycznej filozofii bytu, „w ramach której telos stanowił jedną z czterech przyczyn, tj. źródeł rozumienia rzeczywistości”27. Według niego „nie sposób zakwestionować słuszności zasady: «omnis agens (nie tylko omne agens) agit propter finem». I dlatego teleologiczna interpretacja ludzkiego działania utrzymuje się w filozofii i nauce bez przerwy"28. Równocześnie z utrzymaniem się tej zasady w interpretacji działania bytu, w tym bytu ludzkiego, jednak „od dwóch wieków stwierdza Wojtyła - została on a zakwestionowana w etyce jako wystarczająca zasada interpretacji moralności ludzkiego etosu"29. Mimo że Wojtyła przeciwstawia się w tym względzie kantowskiemu autonomizmowi etycznemu, to jednak fascynuje się jego odkryciem specyficzności i kategoryczności powinności moralnej, opisywanej również przez fenomenologów w postaci kategoryczności aksjologicznej wartości moralnych. Takiej kategoryczności moralności nie znajduje on w samym dynamizmie bytu i natury ludzkiej, i stąd szuka jej na terenie wewnętrznego doświadczenia osoby. W tym względzie przekracza on zarówno noumenalne, kantowskie konstytuowanie się imperatywu kategorycznego, jak też fenomenologiczne, aprioryczne i emocjonalne konstytuowanie się powinności aksjologicznej. W poszukiwaniu swojego rozwiązania pisze: „owe spontanicznie zwrócone ku różnym wartościom ch cen ia (bardzo często jeszcze w biernej raczej postaci zachceń: «chce mi się»), pojawiając się w świadomości, mają charakter swoistych aktów intencjonalnych: wyłaniając się z podmiotu, z różnych warstw i ośrodków jego potencjalności, skierowują się ku przedmiotowi, któremu na imię "wartość»" ${ }^{\text {"30 }}$. To na podstawie owych spontanicznych chceń pojawia się konieczność wyboru, która nie sprzeciwia się wolności. „Wolność woli - stwierdza Wojtyła - ujawnia się w człowieku jako "konieczność» wybierania wśród wartości i rozstrzygania" ${ }^{31}$. To właśnie

27 K. Wojtyła, Transcendencja osoby w czynie a autoteleologia człowieka, dz. cyt., s. 480.

${ }^{28}$ K. Wojtyła, Transcendencja osoby w czynie a autoteleologia człowieka, dz. cyt., s. 480.

29 K. Wojtyła, Transcendencja osoby w czynie a autoteleologia człowieka, dz. cyt., s. 481.

30 K. Wojtyła, Transcendencja osoby w czynie a autoteleologia człowieka, dz. cyt., s. 483.

31 K. Wojtyła, Transcendencja osoby w czynie a autoteleologia człowieka, dz. cyt., s. 483. 
obok spontanicznego i intencjonalnego zwrotu ku wartościom pojawia się zaangażowanie osobowego podmiotu - stanowienie o sobie, czyli samostanowienie. Angażuje i integruje ono wszystkie somatyczne, psychiczne i intelektualne potencjalności człowieka. W ten sposób łączy ono teleologię natury ludzkiej z autoteleologią osoby.

$\mathrm{W}$ autoteleologii nasze osobowe "ja" jako podmiot stanowi o sobie, czyli jest nie tylko podmiotem, ale również przedmiotem dla siebie samego. Jeśli pamiętamy, że telos znaczy nie tylko „cel”, lecz także „kres”, to $\mathrm{w}$ teleologii mamy do czynienia $\mathrm{z}$ pierwszym skierowaniem, a w autoteleologii z drugim. Ten drugi moment wskazuje, że nasze chcenie wraz z naszymi wyborami „znajduje swój właściwy «kres» nie w owych wartościach, do których intencjonalnie zwracają się ludzkie chcenia, ale w samym podmiotowym "ja", które poprzez chcenie jakich kolwiek wartości, poprzez określony ich wybór stanowi zarazemosobiei siebie samego w pewien sposób chce i wybiera"32. $\mathrm{W}$ ten sposób rozproszony świat wartości w opisach fenomenologów przyporządkowany jest wartości wartości, którą jest godność osoby ludzkiej.

Autoteleologia zakłada teleologię, czyli w punkcie wyjścia napotyka to, co jest nam dane $\mathrm{z}$ natury, styka się $\mathrm{z}$ uhierarchizowanym światem wartości, ale w punkcie dojścia skupia się na osobowym ,ja”, jako tym, co zasadnicze. Nie tylko chcę bowiem realizować wartości, ale chcę być dobry. W moralności rozgrywa się nie tyle dramat świata, ile dramat mojego człowieczeństwa.

Tak więc ów teleologiczny zwrot ku dobru czy wartościom uzupełnia Wojtyła przez zwrot ku osobowemu „ja”. W moralności wchodzi w grę moje być albo nie być, moja godność. Horyzontalne skierowanie intencjonalne ku wartościom uzupełnia on wertykalnym skierowaniem ku własnemu ,ja”, gdyż każdy z nas jest świadomy, że w czynie ostatecznie jego sprawa się rozgrywa. Autoteleologia ujawnia więc, że to człowiek jest sam dla siebie celem. „Człowiek na tyle i w taki sposób jest dla siebie celem, na ile jego czyny-

32 K. Wojtyła, Transcendencja osoby w czynie a autoteleologia człowieka, dz. cyt., s. 484. 
oraz zawarte $\mathrm{w}$ tych czynach chcenia, wybory, rozstrzygnięcia - znajdują w samym człowieku swój kres. Kres ten znajdują zaś na gruncie transcendentnego odniesienia do prawdy (a wraz tym również do dobra czy piękna) [...]"33. Skutkiem takiego odniesienia sądy sumienia mają charakter kategoryczny, nie chodzi w nich bowiem tylko o realizację jakiegoś dobra, lecz o potwierdzenie albo zranienie naszego człowieczeństwa.

Można powiedzieć, że kresem autoteleologii jest spełnienie siebie samego. Owo spełnienie ma charakter bezwzględności dobra, charakter czegoś kategorycznego, absolutnego. Odkryta prawda o człowieku, o jego godności, sąd prawego sumienia ujawniają kategoryczne, bezwzględne dobro moralne. To właśnie tak rozumiana autoteleologia kresu nie przekreśla teleologii natury, ale pozwala ją realizować na płaszczyźnie moralnej. „Zakłada ona całą teleologię chceń i wyborów, poprzez którą człowiek stale jest włączony w aksjologiczną (a z kolei teleologiczną) strukturę rzeczywistości, w obrębie której bytuje i działa. [...] Autoteleologia oznacza tylko osobowy modus tego otwarcia. Modus ten musi być wieloraki, tak np. inny w stosunku do rzeczy, inny w stosunku do osób"34.

W szkicu, napisanym przez Wojtyłę po opublikowaniu Osoby i czynu w 1972 roku, dotyczącym podstaw etyki i zatytułowanym Człowiek w polu odpowiedzialności, wyraźnie występuje kwestia związku teleologii natury z autoteleologią osoby. Autor przyznaje słuszność przeprowadzonej przez Kanta krytyce utylitarystycznie rozumianej teleologii, a jednocześnie odrzuca sugestie, jakoby owa krytyka mogła podważyć rozumienie teleologii w nurcie arystotelesowsko-tomistycznym. Zauważa, że w tej ostatniej tradycji oprócz bonum delectabile i bonum utile, odróżniono specyficzne dla moralności bonum honestum. „Zdolność poznawania, wybierania i urzeczywistniania dobra godziwego (bonum honestum) stwierdza Wojtyła - stanowi podstawę normy etycznej i normowania"35.

K. Wojtyła, Człowiek w polu odpowiedzialności, dz. cyt., s. 57. 
Należy jego zdaniem pogłębić rozumienie tego dobra poprzez to, że nie tylko wyznacza ono dziedzinę moralności, ale „równocześnie odpowiada godności człowieka - osoby oraz tejże godności służy" ${ }^{36}$. Ów element godnościowy akcentuje Wojtyła mocniej niż filozofia klasyczna. Moralność jest czymś bogatszym niż spontaniczne intencjonalne skierowanie ku dobru czy wartościom. W grę wchodzi w nim moje „ja” osobowe. " "Chcę być dobrym, nie chcę być złym» - to nie tylko zwyczajne intencjonalne chcenie, to sama racja bytu osoby w porządku aksjologicznym" ${ }^{37}$.

To właśnie na poziomie osobowym, na którym sąd sumienia staje się normą postępowania i wydaje nakaz działania, rodzi się powinność, norma moralna. Zaakcentowanie tego poziomu osobowej godności, osobowego sumienia nie jest - zdaniem Wojtyły - krytyką etyki św. Tomasza, gdyż właśnie w tej etyce szeroko opracowano strukturę sumienia w postaci prasumienia i sumienia. Jego zdaniem tomistyczne, intelektualistyczne ujęcie sumienia raczej jako prawdy myślenia należy uzupełnić o ujęcie sumienia jako prawdy działania i prawdy samego bytu osoby ${ }^{38}$. Łączy on obie perspektywy, teleologiczną i autoteleologiczną, pisząc: „powinność, a poprzez nią prawda o dobru, w pewien sposób «hamuje i osadza w miejscu» cały «naturalny» dynamizm podmiotu, równocześnie zaś dynamizuje go w nowy zupełnie sposób"39. Jest to dynamizowanie poprzez samo-panowanie, samo-posiadanie, samostanowienie. W centrum tego dynamizmu jest stawanie się dobrym jako człowiek, jest godność osobowego „ja”. Stanowisko to prowadzi do reinterpretacji tomistycznej normy moralności „bonum est faciendum” w kierunku normy personalistycznej w sformułowaniu Tadeusza Stycznia - „persona est affirmanda et amanda propter se ispsam” (osobie jako osobie należna jest afirmacja, czyli miłość, dla niej samej).

Zdaniem Wojtyły norma „bonum est faciendum malum vitandum”, jako „primum principium practicum”, odnosi się niejako technicznie

\footnotetext{
36 K. Wojtyła, Człowiek w polu odpowiedzialności, dz. cyt., s. 57.

37 K. Wojtyła, Człowiek w polu odpowiedzialności, dz. cyt., s. 58.

38 Zob. K. Wojtyła, Człowiek w polu odpowiedzialności, dz. cyt., s. 59.

39 K. Wojtyła, Człowiek w polu odpowiedzialności, dz. cyt., s. 59.
} 
do działania. Nie ujawnia ona w pełni specyfiki tego, co moralne, a co np. dostrzegamy w kategoryczności sądów sumienia. Przeakcentowanie owej celowościowej tendencji naszej natury przysłoniło dostrzeżenie tego, co rozgrywa się na poziomie osoby i sumienia, gdzie napotykamy kategoryczne normy działania. To z tego poziomu, gruntowniej poznając rację dobra i zła moralnego, zwracamy się do realizacji celu. To właśnie norma nadaje działaniu celowemu charakter moralny, a nie odwrotnie.

$\mathrm{W}$ związku z powyższym Wojtyła uzupełnia postawione u podstaw etyki prawo naturalne o normę personalistyczną. „Jest ona w stosunku do niego komplementarna, a jej miejsce w etyce wynika $\mathrm{z}$ faktu, że właściwie ogół norm występujących w ludzkiej moralności określa nade wszystko zasadę odniesienia do osoby; zawsze zawiera się w nich zasada odniesienia do osoby własnej (być dobrym jako człowiek), a także przynajmniej pośrednio - jakaś zasada odniesienia do innej (drugiej) osoby lub osób"40.

Norma personalistyczna nie niweczy prawa natury. Prawo to podkreśla, że człowiek tkwi w świecie wielości bytów i ich natur. „Norma personalistyczna stara się uwydatnić szczególna pozycję człowieka jako osoby, jego stąd wynikającą odrębność i transcendencję" ${ }^{\text {"41 }}$. Nie pomniejsza ona, ale głębiej wydobywa naturę człowieka, to, że jest osobą. Porządek normatywny zapisany w porządku bytów i natur odczytuje ona przez "podniesienie go niejako na poziom umysłu i ducha, na poziom osoby"42. Człowiek nie w sposób bierny, lecz czynny, przez poznanie i swoją wolność, uczestniczy w prawie odwiecznym. W ten sposób ujawnia się „participatio legis aeternae in rationali creatura”.

Norma personalistyczna mocniej ujawnia specyfikę, bezinteresowność, ale i kategoryczność moralności. „Wyznacza ona kierunek uzasadnienia norm ludzkiej moralności. Jest to kierunek [...] inny nieco od kierunku prawa natury, chociaż wobec niego nie przeciwstawny, raczej komplementarny". [...]. Bierzemy [w niej - dod. T. B.] pod uwage 
prawdę o ponad-utylitarnym znaczeniu osoby, o jej auto-teleologii, która wyklucza pozycję «środka do celu» - wreszcie bierzemy pod uwagę szczególną wartość miłości, która jako zasada postępowania odpowiada najpełniej tej rzeczywistości, jaką stanowi osoba" ${ }^{\text {"33 }}$.

Podsumowując, można powiedzieć, że w swej antropologii Wojtyła nie tylko w swych deklaracjach, które wielokrotnie powtarzał, ale i w swych teoretycznych propozycjach dokonał swoistej syntezy filozofii podmiotowej z przedmiotową. Można ten nurt myślenia nazwać personalizmem realistycznym, różnym od personalizmu transcendentalnego Kanta i jego kontynuatorów. Personalizm ten wykorzystuje nowożytne i współczesne odkrycia specyfiki moralności, które spotykamy zarówno w etyce Kanta, jak i w aksjologii fenomenologów, i wkomponowuje je w realistyczne ujęcia człowieka i moralności. Stanowisko to zainspirowało twórczą dyskusję z fenomenologami i z tomistami, prowadząc do głębszego ujęcia faktu moralności, lepszego ujęcia bonum honestum, godności ludzkiej, wolności i sumienia oraz do uzupełnienia normy moralności opartej na analizie natury ludzkiej o normę opartą na afirmacji godności osoby ludzkiej. Personalizm realistyczny Wojtyły różni się od personalizmu esencjalnego tomistów, różni się również od personalizmu fenomenologów. Personalizm ten wchodzi też w spór z personalizmem transcendentalnym, w którym rola natury ludzkiej w moralności $\mathrm{w}$ większym czy mniejszym stopniu jest zanegowana ${ }^{44}$.

Wypracowana przez Wojtyłę własna antropologia i etyka pozwoliła mu krytycznie odnieść się do negacji natury ludzkiej w uzasadnianiu moralności we współczesnych nurtach teologicznych. Praktyczne zastosowanie oryginalnej syntezy antropologicznej i etycznej możemy prześledzić choćby w encyklice Jana Pawła II Veritatis splendor ${ }^{45}$. Tam właśnie z pozycji owego personalistycznego realizmu przeciwstawił się

$43 \quad$ K. Wojtyła, Człowiek w polu odpowiedzialności, dz. cyt., s. 87.

44 Por. T. Biesaga, Personalizm realistyczny a personalizm transcendentalny w sporze o uzasadnianie norm moralnych, w: W kręgu inspiracji personalizmu etycznego: Ślipko - Tischner - Styczeń, red. P. Duchliński, Kraków 2012, s. 133-142.

45 Jan Paweł II, Encyklika Veritatis splendor, Kraków 1993, rozdz. III: Wybór podstawowy a konkretne postępowanie. 
on tzw. nowej teologii moralnej, będącej efektem przewrotu transcedentalnego. Odrzucił w niej oparcie moralności jedynie na podstawowym wyborze, autoprojekcie siebie i autoprojekcie społecznym, czyli na kategoriach ignorujących to, co dla moralności wnosi natura ludzka. Odrzucił on w tej propozycji podporządkowanie rozumu wolności. Jego zdaniem błędem jest zastąpienie w moralności rozumu receptywnego, rozpoznającego naturę i godność ludzką, rozumem kreatywnym, podporządkowanym wolności, który w tym podporządkowaniu wyłania i konstruuje projekt człowieka.

Praktyczne zastosowanie personalizmu realistycznego, ujawnione najpierw w Miłości i odpowiedzialności ${ }^{46}$ można zauważyć w katechezach Jana Pawła II dotyczących natury i cielesności mężczyzny i kobie$t^{47}$. $Z$ analiz tych wyłania się teza, że wolność przeciwstawiona naturze ludzkiej, naturze kobiety, mężczyzny, naturze małżeństwa i rodziny jest destrukcyjna i niszcząca.

Można z tego wyciągnąć wniosek, że Wojtyłowski personalizm realistyczny jest bezpieczną dla Kościoła i kultury syntezą starej i nowej chrześcijańskiej tradycji moralnej, jest syntezą, która chroni nas przed skutkami dualistycznej antropologii, przed skrajnościami zarówno naturalistycznej, jak i idealistycznej koncepcji człowieka. Pierwsza bowiem z nich, absolutyzując procesy przyrodnicze, podważa wolność człowieka, a druga, absolutyzując wolność, podważa jego naturę. Obie rozbijają psychofizyczną jedność człowieka i niszczą albo jego physis albo jego psyche. Dopiero integralne ujęcie człowieka $\mathrm{w}$ antropologii Wojtyły unika tych skrajności i pozwala pełniej uzasadnić zasady moralne.

46 K. Wojtyła, Miłość i odpowiedzialność, red. T. Styczeń, J. W. Gałkowski, A. Rodziński, A. Szostek, Lublin 1982 (Człowiek i Moralność, 1).

47 Jan Paweł II, Mężczyzna i niewiastą stworzył ich. Chrystus odwołuje się do „początku”, Città del Vaticano 1980. 


\section{Bibliografia}

Biesaga T., Personalizm realistyczny a personalizm transcendentalny $w$ sporze o uzasadnianie norm moralnych, w: $W$ kręgu inspiracji personalizmu etycznego: Ślipko - Tischner - Styczeń, red. P. Duchliński, Kraków 2012, s. 133-142.

Gałkowski J., Natura, osoba, wolność, „Analecta Cracoviensia” 5-6 (1973-1974), s. 177-182. Gogacz M., Hermeneutyka „Osoby i czynu” (Recenzja książki Księdza Kardynała Karola Wojtyły Osoba i czyn), Kraków 1969), Analecta Cracoviensia" 5-6 (1973-1974), s. 125-138. Jan Paweł II, Encyklika Veritatis splendor, Kraków 1993.

Jan Paweł II, Mężczyzna i niewiasta stworzył ich. Chrystus odwołuje się do "początku”, Città del Vaticano 1980.

Jaworski M., Koncepcja antropologii filozoficznej w ujęciu Kardynała Karola Wojtyły (Próba odczytania w oparciu o studium „Osoba i czyn”), „Analecta Cracoviensia” 5-6 (1973-1974), s. 91-106.

Kalinowski J., Metafizyka i fenomenologia osoby ludzkiej. Pytania wywołane przez „Osobę i czyn”, „Analecta Cracoviensia” 5-6 (1973-1974), s. 63-71.

Krąpiec M. A., Książka Kardynała Wojtyły monografią osoby jako podmiotu moralności, „Analecta Cracoviensia” 5-6 (1973-1974), s. 57-61.

Tischner J., Metodologiczna strona dzieła „Osoba i czyn”, „Analecta Cracoviensia” 5-6 (1973-1974), s. 85-89.

Wojciechowski T., Jedność duchowo-cielesna człowieka w książce „Osoba i czyn”, „Analecta Cracoviensia" 5-6 (1973-1974), s. 191-199.

Wojtyła K., Człowiek w polu odpowiedzialności, red. A. Szostek, Rzym-Lublin 1991.

Wojtyła K., Elementarz etyczny, w: K. Wojtyła, Aby Chrystus się nami posługiwał, Kraków 1980, s. 129-182.

Wojtyła K., Miłość i odpowiedzialność, red. T. Styczeń, J. W. Gałkowski, A. Rodziński, A. Szostek, Lublin 1982 (Człowiek i Moralność, 1).

Wojtyła K., Osoba i czyn, red. M. Jaworski, Kraków 1969.

Wojtyła K., Rozważania o istocie człowieka, Kraków 1999.

Wojtyła K., Transcendencja osoby w czynie a autoteleologia człowieka, w: K. Wojtyła, „Osoba i czyn” oraz inne studia antropologiczne, red. T. Styczeń, W. Chudy, J. W. Gałkowski, A. Rodziński, A. Szostek, Lublin 1994, s. 477-490 (Człowiek i Moralność, 4).

Wojtyła K., Wykłady lubelskie, red. T. Styczeń, J. W. Gałkowski, A. Rodziński, A. Szostek, Lublin 1986 (Człowiek i Moralność, 3). 


\section{Abstrakt \\ Autoteleologia osoby a teleologia natury w antropologii Karola Wojtyły}

Artykuł rekonstruuje i analizuje Wojtyłowską propozycję przezwyciężenia dualizmu antropologicznego przez syntezę teleologicznych tendencji natury ludzkiej z autoteleologią wolności osoby. Propozycja ta zmierza równocześnie do syntezy filozofii bytu i filozofii świadomości, inaczej syntezy podmiotowego i przedmiotowego, subiektywnego i obiektywnego ujęcia człowieka oraz norm moralnych. Droga ta jest trudniejsza niż obrana przez antropologię spirytualistyczną lub jej przeciwieństwo, antropologię naturalistyczną, czy materialistyczną. Drogę tę można nazwać filozofią i antropologią integralną, łączącą w sobie pełne ujęcie bytu ludzkiego.

\section{Słowa kluczowe}

Karol Wojtyła, antropologia, teleologia, autoteleologia, natura człowieka, osoba, personalizm realistyczny

\section{Abstract \\ Autoteleology of person and teleology of nature in the Karol Wojtyła's anthropology}

The paper is reconstructing and analyzing the Karol Wojtyła's proposition to overcome dualism in anthropology by developing a synthesis of teleological tendency of human nature and autoteleology of personal freedom. This proposition leads up also to synthesis of philosophy of being with philosophy of consciousness, that is synthesis of subjective and objective approach to a human being and his moral norms. This way is more difficult in comparison with spiritual anthropology or with its contrariety - naturalistic or materialistic anthropology. We can call it integral anthropology, because it present a complete conception of human being.

\section{Keywords}

Karol Wojtyła, anthropology, teleology, autoteleology, nature of human being, person, realistic personalism 